I N T E R N A T I O N A I I E G A L

M A T E R I A L S

\author{
INDEX \\ Volumes I and II \\ $1962 \& 1963$
}
American Society of International Law
2223 Massachusetts Avenue, N.W. Washington 8 , D.C.


INTERNATIONAL LEGAL MATERIALS

TABLE OF CONTENTS

Volumes I and II

JUDICIAL AND SIMILAR PROCEEDINGS

Council of Europe: Pataki and Dunshirn v. Austria (application of European Convention on Human Rights). Committee of Ministers decision, september 13, 1963.................. 2:1123 Nov 63

Denmark: Lucky star case (offshore broadcasting; territorial jurisdiction). Proceedings in the criminal Court in Lyngby, August $15,1962 \ldots \ldots \ldots \ldots \ldots \ldots \ldots \ldots \ldots \ldots \ldots \ldots \ldots \ldots \ldots \ldots \ldots \ldots$ Mar 63

European Economic Community: Van Gend \& Loos $\underline{v}$. Dutch Fiscal Administration (internal effect of Article 12 of the E.E.C. Treaty). Decision of the Court of Justice of the European Communities, February 5, 1963.................... 2:505 May 63

India: Notes on recent judicial decisions:

Buland Sugar Co. $v$. Union of India (state succession). Decision of High Court of Allahabad, $1962 \ldots \ldots \ldots \ldots 2: 645$ Jul 63

Deb $v$. State of Orissa (state succession). Decision of Supreme court of India, $1962 \ldots \ldots \ldots \ldots \ldots \ldots \ldots \ldots 2: 645$ Jul 63

State of Saurashtra $\underline{v}$. Abdullah (state succession). Decision of Supreme court of India, $1962 \ldots \ldots \ldots \ldots 2: 645$ Jul 63

Ahmad $\mathrm{v}$. State of Uttar Pradesh (loss of citizenship). Decision of High Court of Allahabad, 1962....... 2:646 Jul 63

Ahmed $\underline{v}$. Union of India (loss of citizenship). Decision of supreme Court of India, $1962 \ldots \ldots \ldots \ldots \ldots 2: 646$ Jul 63

Manusri $\underline{v}$. State of Gujarat (loss of citizenship). Decision of High Court of Gujarat, $1962 \ldots \ldots \ldots \ldots 2: 646$ Jul 63

Masthan Sahib $\mathrm{v}$. Chief Commissioner, Pondicherry (territory; effect of executive statement). Decision of supreme Court of India, 1962......... 2:646

United Arab Republic V. Ali (sovereign immunity). Decision of Calcutta High Court, $1962 \ldots \ldots \ldots \ldots \ldots 2: 646$ Jul 63

Menon $\mathrm{v}$. Collector of Customs, Madras (domestic effect of international convention). Decision of High Court of Madras, 1962............... 2:648

Société de Traction $\underline{v}$. Kamani (arbitration between Indian and foreign companies). Decision of supreme court of

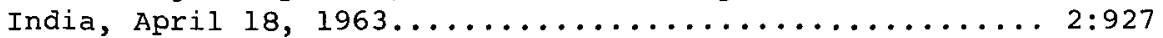

International court of Justice:

Barcelona Traction, Light \& Power Co., case concerning (Belgium $\mathrm{v}$. Spain). Communique on institution of new proceedings before the Court, June 21 , 1962......... 1:74 Advisory opinion concerning certain expenses of the United Nations in the Congo and Middle East, July 20, 1962..... 1:169 South West Africa cases (Ethiopia $\underline{v}$. South Africa; Liberia

$v$. South Africa). Communique summarizing the decision of the Court on preliminary objections, December 12,

$1962 \ldots \ldots \ldots \ldots \ldots \ldots \ldots \ldots \ldots \ldots \ldots \ldots \ldots \ldots \ldots \ldots \ldots \ldots$. $2: 199$

Pakistan: Notes on recent judicial decisions:

Hse Yung Hsieh $\underline{v}$. The State (acquisition of citizenship). Decision of High Court of Dacca, 1962..... 2:648

Shome $\underline{v}$. Province of East Bengạl (extradition), Decision of High Court of Dacca, 1962...........2:648 Jul 63

United Kingdom: Enahoro case (extradition of Nigerian political leader).

Regina $\underline{v}$. Governor of Brixton Prison, ex parte Enahoro. Proceedings in High Court of Justice, Queen's Bench Division, January 14-15, 1963....... 2:346

Enahoro $v$. Federation of Nigeria. Proceedings in House of Lords, February 6, 1963............ 2:348 
United states: Sabbatino case (Cuban nationalizations; act of state doctrine). Banco Nacional de cuba $\underline{v}$. Sabbatino and Farr, Whitlock \& Co.

Decision of U.S. Court of Appeals, Second Circuit,

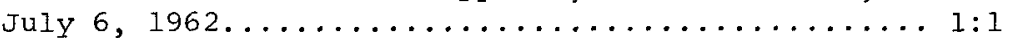

U.S. Solicitor General's memorandum suggesting review by U.S. Supreme Court, December $28,1962 \ldots \ldots 2: 212$ Jan 63

Briefs filed in U.S. Supreme court in response to Solicitor General's memorandum, January, 1963.... 2:366 Mar 63

Brief amicus curiae of the United States in U.S. Supreme Court, september 10, 1963............2:1009 sep 63

Summaries of oral argument in U.S. Supreme court,

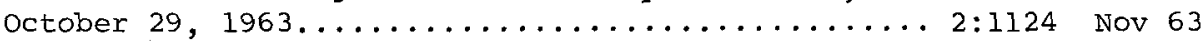

Brief in U.S. Supreme Court for petitioner Banco Nacional de Cuba, August 31, 1963...........2:1143 Nov 63

Brief in the U.S. Supreme Court of Compania Azucarera Vertientes-Camaguey de Cuba, september 30,

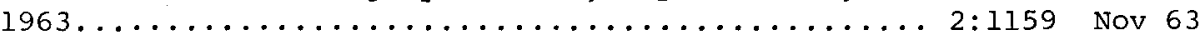

Brief in the U.S. Supreme Court of respondent Farr, Whitlock \& Co., October 2, 1963.............2:1176 Nov 63

Reply brief in the U.S. Supreme court of petitioner

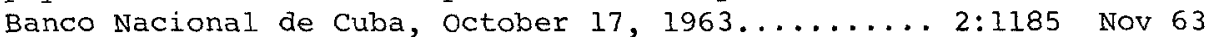

Rebuttal brief in the U.S. Supreme court for respondent Farr, Whitiock \& Co., October 22, 1963... 2:1190 Nov 63

Foreign-flag labor cases (application of U.S. labor legislation to foreign crews and vessels).

Incres Steamship Co., Itd. $\mathrm{v}$. International Maritime Workers Union, et al.

Brief in U.S. Supreme Court of United Kingdom as amicus curiae, June $25,1962 \ldots \ldots \ldots \ldots \ldots 1: 58$ New York Court of Appeals opinion, July 7, 1961. 1:63

U.S. Supreme Court decision, February 18, 1963.. 2:362

Aug 62

National Labor Relations Board $\mathrm{v}$. Sociedad Nacional de Marineros de Honduras; National Labor Relations Board $v$. Empresa Hondurena de Vapores; National Maritime Union of America $\underline{v}$. Empresa Hondurena de Vapores.

Decision of U.S. Supreme Court, February 18,

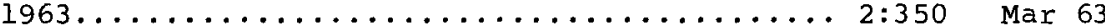

Bahia de Nipe cases (Cuban nationalization; sovereign immunity). Rich and Precha $\underline{v}$. Naviero Vacuba S.A. and Republic of Cuba; Mayan Lines, S.A. $\underline{v}$. Republic of Cuba and M-V Bahia de Nipe; United Fruit Sugar Co. v. 5,000 Tons of Sugar, in rem, and Augustin Albella.

Application to U.S. Supreme Court for stay filed by James Rich and walter Precha, September 1961..... 1:278 Memorandum for United States in opposition, Septem-

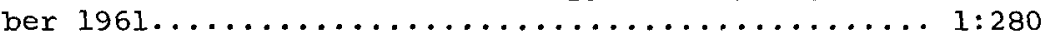

Application to U.S. Supreme Court for stay filed by Mayan Lines, S.A., September 1961............ 1:292

Memorandum for United states in opposition, septem-

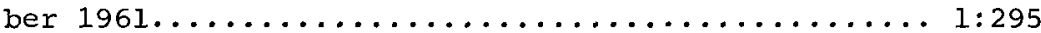

Application to U.S. Supreme court for stay filed by United Fruit Sugar Company, september 1961....... 1:299 Memorandum for United states in Opposition, septem-

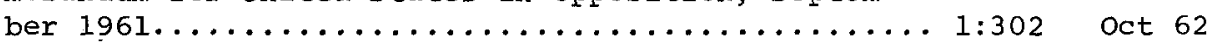

Regierungspraesident Land Nordrhein Westfalen $\mathrm{V}$. Rosenthal (enforceability of foreign administrative award). Decision of New York Supreme Court, Appellate Division, October 23, 1962. Noted,.................. 2:205 Jimenez case (extradition; political offense).

Jimenez $\underline{v}$. Aristequieta. Decision of U.S. Court of Appeals, 5th Circuit, December 12, 1962. Noted,... 2:206

Jimenez $\underline{\mathrm{v}}$. United States. Decision of U.S. Supreme Court, August 23, 1963.................. 2:940

Oct 62

Oct 62

Oct 62

Oct 62

Oct 62

$\operatorname{Jan} 63$

$\operatorname{Jan} 63$

Sep 63

Mann v. Compania Petrolera Trans-Cuba, S.A. (Cuban nationalization; act of state doctrine). Decision of New York Supreme Court, Appellate Division, November 15, 1962.

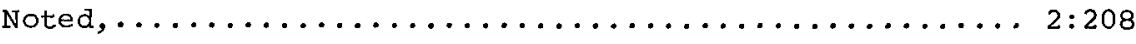


Paǹ American Life Insurance cases (Cuban life insurance contracts).

Vento Jaime $\mathrm{v}$. Pan American Life Insurance Co.;

Menendez Rodriguez $\underline{v}$. Pan American Life Insurance Co. Decision of U.S. Court of Appeals, 5th Cir-

cuit, October 17, 1962. Noted,..............2:209 Jan 63

Theye y Ajuria $\underline{v}$. Pan American Life Insurance Co.

Decision of Louisiana Court of Appeal, 4 th Cir-

cujt, June 14, 1963. Noted,.............2:950 sep 63

Arctic Maid Fisheries $\underline{v}$. State of Alaska (territorial waters).

Note on final settlement during proceedings in supreme Court of Alaska, April 1963...........2:524 May 63

Letter of U.S. Secretary of State, January 15, 1963.. 2:527 May 63

Confederation Life Association $\underline{v}$. Ugalde (effect of Cuban currency laws on life insurance contracts). Decision of District Court of Appeal of Florida, 3rd District, March 26, 1963; rehearing denied April 11, 1963...... 2:530

Civil Aeronautics Board order and correspondence concerning north and mid-Atlantic fares, May $1963 \ldots \ldots \ldots \ldots$ 2:649 Ju1 63

National Institute of Agrarian Reform $v$. Kane (act of state doctrine). Decision of District Court of Appeal of Florida, 3rd District, May 14, 1963, rehearing denied, May 31, 1963....................... 2:658

Ju1 63

\section{LEGISLATION AND REGULATIONS}

Algeria: Investment Code, effective August 2, 1963........ 2:1111 Nov 63 Brazil: Decree providing for expropriation of public utility

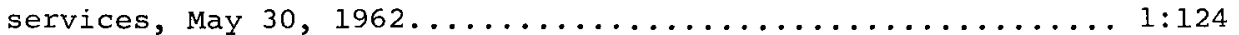

Law relating to expatriation of profits earned by foreign investors, september 27, 1962................. 1:306

Regulations relating to expatriation of profits earned by foreign investors, issued october $24,1962 \ldots \ldots \ldots \ldots \ldots$ 2:100

Canada: Government announcement of establishment of 12-mile

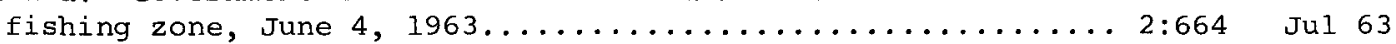

Ceylon: Ceylon Petroleum Corporation Act, May 29, 1961..... 1:126 United States statement on suspension of assistance

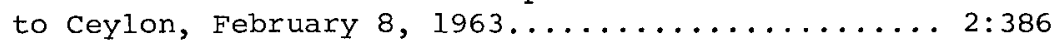
Ceylon statement on suspension of United States assistance, February 8, 1963.............. 2:393

Ceylon Petroleum Corporation Act amendment (oil distribution take-over), passed Parliament August 20, 1963... 2:951. United States statement on the amendment, July 25 ,

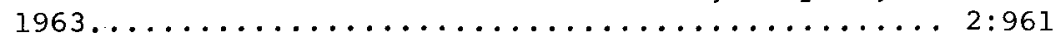

United Kingdom statement on the amendment, July 26 ,

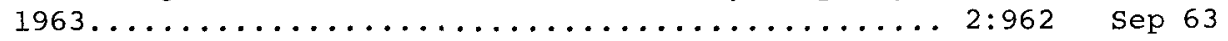

Ceylon statement in response to the United States statement, July $25,1963 \ldots \ldots \ldots \ldots \ldots \ldots \ldots \ldots \ldots \ldots$ sep 63

Joint statement of Esso Standard Eastern, Inc., Caltex Petroleum Co., and Shell oil Company on the amendment, July $29,1963 \ldots \ldots \ldots \ldots \ldots \ldots \ldots \ldots \ldots$ 2:967

European Economic Community: Regulation 27 (relating to anti-

trust measures), May $3,1962 \ldots \ldots \ldots \ldots \ldots \ldots \ldots \ldots \ldots \ldots \ldots \ldots \ldots$. . . 320

Practical guide concerning Articles 85 and 86 of the treaty establishing the E.E.C. and implementing regulations (anti-trust regulations), october 1, 1962..... 2:104

communiques relating to exclusive dealership agreements and patent license agreements, November 9, $1962 \ldots \ldots \ldots 2: 138$

Regulation 153 , on registration of two-party trade agree-

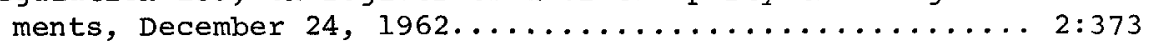

Communique concerning exclusive representation contracts with commercial representatives, December 24, 1962..... 2:375

Communique concerning patent license agreements, Decem-

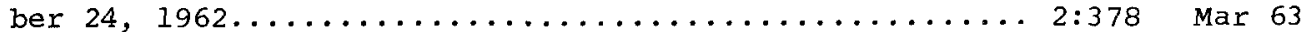


Ghana: Capital Investments Act, April 19, $1963 \ldots \ldots \ldots \ldots \ldots \ldots 2: 666$ Kuwait: Decree establishing Kuwait Fund for Arab Economic

Development, issued December 31, 1961.............. 1:160

Charter of Kuwait Fund for Arab Economic Development,

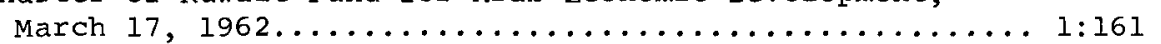

Mexico: Amendments to Article 123 of constitution (labormanagement relations and profit sharing), effective Novem-

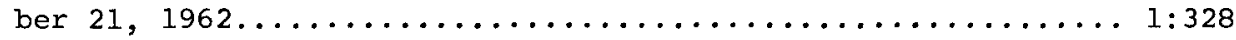

Spain: Decree liberalizing procedures for foreign majority ownership of certain investments, April 19, 1963........ 2:676

Tanganyika: Foreign Investments (Protection) Act, approved

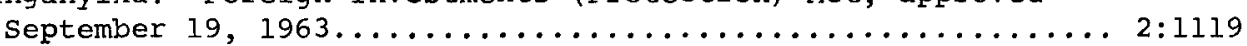

United Arab Republic: Decree-law prohibiting foreign ownership of agricultural land, effective January 19, 1963..... 2:488

United States: Defense Department: Directive regarding

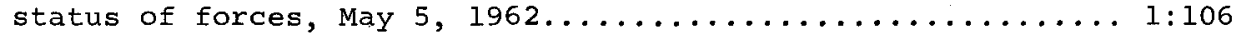

Sugar Act amendments of 1962 (regarding expropriation and discriminatory treatment of American-owned properties), approved July 13, 1962............... 1:116

Foreign Assistance Act of 1962, Sec. 301(d) regarding certain restrictions on U.S. aiđ), approved August 1, 1962. 1:118

state Department: statement on limiting foreign aid in cases of nationalization, April 1962............. 1:121

Communications Satellite Act of 1962, approved August 31,

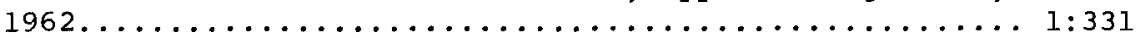

Foreign Aid Appropriations Act, Sec. 107 (limiting assistance to countries aiding Castro regime in Cuba), approved October 23, 1962................... 1:339

Trade Expansion Act of 1962, approved October 11, 1962... 1:340

United Nations Loan Act, approved October 2, 1962...... 1:372

Federal Rules of Civil procedure amendments (new provisions regarding international civil procedure), January

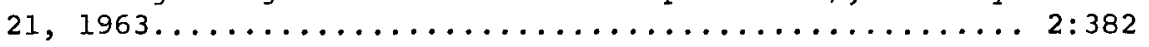

Regulation on shipping in foreign-flag vessels engaged in trade with cuba, February $6,1963 \ldots \ldots \ldots \ldots \ldots \ldots \ldots \ldots$ 2: 384

State Department: Regulations on international judicial procedure (notarial and related services), November 26,

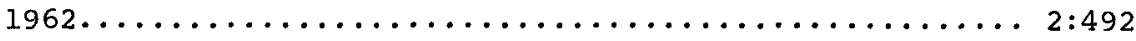

Administrative orders regarding trade agreements and adjustment assistance programs, as of June 15, 1963... 2:678

State Department: Summary of claims to extended territorial waters or fishing zones since 1960 U.N. Law of the sea Conference, June 17, 1963............ 2:1122

Viet-Nam: Decree-law regulating investments, promulgated February 16, 1963.......................... 2:494

REPORTS

European Economic Community: Report of the Commission on the action programme for the second stage, October $24,1962 \ldots . . .2 .1$

Indonesia, Malaya, and Philippines: Report and recommendations of foreign ministers concerning closer association, June 11,

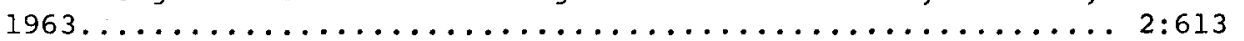

Institute for Defense Analyses: Summary report on verification and response in disarmament agreements, dated November 15, 1962, released January $10,1963 \ldots \ldots \ldots \ldots \ldots \ldots \ldots \ldots \ldots$ 2: 320

Israel: Report of Ministerial Committee on deportation of

$\mathrm{Dr}$. Robert soblen, January 13, 1963............... 2:419 May 63

Malaya, North Borneo, Sarawak, and United Kingdom: Report of Inter-Governmental Committee on proposed Federation of Malaysia, February $1963 \ldots \ldots \ldots \ldots \ldots \ldots \ldots \ldots \ldots \ldots \ldots \ldots \ldots$ 2:423 United Nations: Congo.

Report of the officer in charge of United Nations operations in the Congo, November $26,1962 \ldots \ldots \ldots 2: 82$

Acting Secretary-General's plan of national reconciliation in the Congo, November $29,1962 \ldots \ldots \ldots 2: 92$ May 63

Ju1 63

Aug 62

Aug 62

oct 62

Jul 63

Nov 63

May 63

Aug 62

Aug 62

Aug 62

Oct 62

Oct 62

oct 62

oct 62

Mar 63

Mar 63

May 63

Jul 63

Nov 63

$\operatorname{Jan} 63$

Jul 63

Mar 63

May 63

$\operatorname{Jan} 63$

Jan 63
Aug 62 
United Nations: Congo (cont.):

Report of Secretary General on implementation of plan of national reconciliation in the congo,

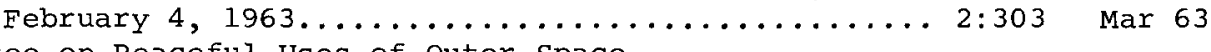

Committee on Peaceful Uses of Outer space.

Report of Legal Sub-Committee on work of first session, July $9,1962 \ldots \ldots \ldots \ldots \ldots \ldots \ldots \ldots \ldots \ldots \ldots$ Ang 62

Report of the Committee to the 17 th session of the General Assembly, september 27, 1962.......... 1:373

Report of Legal sub-Committee on work of second session, May $6,1963 \ldots \ldots \ldots \ldots \ldots \ldots \ldots \ldots \ldots \ldots \ldots \ldots 2: 620$ Jul 63

Report of the Committee to the 18th session of the General Assembly, september 24, 1963.........2:1058 Nov 63

Report of working group on administrative and budgetary

procedures, March 29, 1963................ 2:464 May 63 Yemen.

Report of Secretary General to the security council on developments relating to Yemen, May 27, 1963... 2:636 Jul 63

Report of Secretary General to the Security council on the financial implications of the United Nations observation mission in Yemen, June 3, 1963... 2:638

Report of secretary General to the security Council on developments relating to Yemen, June 7, 1963...2:642 Jul 63

Request of the U.S.S.R. that the Security Council be convened to consider developments in Yemen, June $8,1963 \ldots \ldots \ldots \ldots \ldots \ldots \ldots \ldots \ldots \ldots \ldots \ldots \ldots \ldots \ldots$ 2:643

Resolution establishing an observation mission in Yemen, June 11, $1963 \ldots \ldots \ldots \ldots \ldots \ldots \ldots \ldots \ldots \ldots \ldots \ldots 44$ Jul 63

United States:

State Department statement on major instances of expropriation since world War II, May 7, 1962........... 1:76 Aug 62

Agency for International Development statement on status of investment guarantee program, April 11, 1962....... 1:82

President's report to congress of activities under the Communications Satellite Act, January $31,1963 \ldots \ldots \ldots$ 2:332 Legislative Reference Service report on expropriation of American-owned property by foreign governments in the twentieth century, July 19, 1963............. 2:1066 Nov 63

Aug 62

Mar 63

\section{TREATIES AND AGREEMENTS}

Aden, Federation of South Arabia, and United Kingdom: Draft treaty for accession of Aden to Federation of South Arabia,

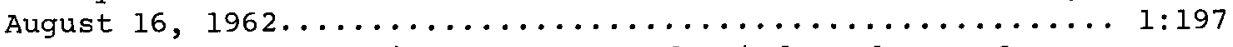

Algeria and France: Evian agreements for independence of

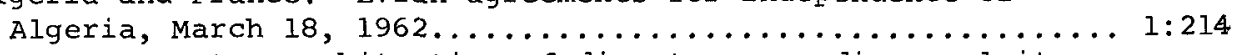
Agreement on arbitration of disputes regarding exploita-

tion of the Saharan subsoil, signed June 26, 1963..... 2:1025 Nov 63

Argentina and United States: Investment guaranty agreement (extended coverage; arbitration arrangements), signed

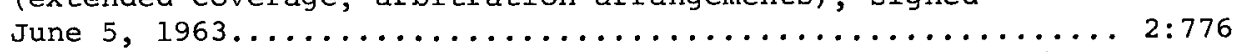

Belgium and United States: Atomic energy agreement amendment, signed August $7,1963 \ldots \ldots \ldots \ldots \ldots \ldots \ldots \ldots \ldots \ldots \ldots \ldots . \ldots \ldots 2$

Brazil and United states: Agreement on economic and financial assistance, March 25, 1963...................... 2:537

Cameroon and United Kingdom: Agreement on commercial and economic co-operation, signed July 29, $1963 \ldots \ldots \ldots \ldots \ldots \ldots \ldots$ 2: 1030

Canada, Japan, and United states: Summary of discussions on North Pacific Fisheries Convention, released June 21, 1963... 2:682

China and Pakistan: Boundary agreement, signed March 2, 1963.. 2:541

Colombo Conference: Proposals on Indian-Chinese border dis-

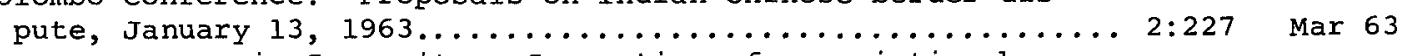

European Economic Community: Convention of association between the E.E.C. and associated African states, signed

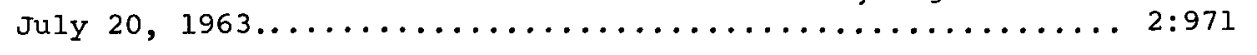

oct 62

oct 62

Jul 63

Sep 63

May 63

Nov 63

Jul 63

May 63

sep 63 
France and Germany: Treaty of cooperation, signed January 22,

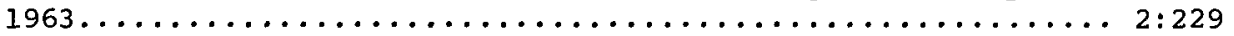

Preamble to German act ratifying the treaty, approved

May $31,1963 \ldots \ldots \ldots \ldots \ldots \ldots \ldots \ldots \ldots \ldots \ldots \ldots \ldots \ldots \ldots \ldots$ 2:705 Ju1 63

European Nuclear Energy Agency: Supplementary convention on third-party liability in the field of nuclear energy,

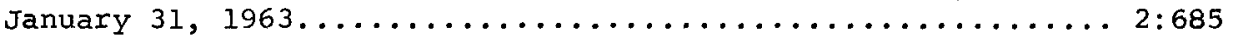

General Agreement on Tariffs and Trade: Resolution on trade

negotiations, May $21,1963 \ldots \ldots \ldots \ldots \ldots \ldots \ldots \ldots \ldots \ldots \ldots \ldots$ 2:703 Jul 63

India:

United Kingdom and United states: Air defense agreement, signed July $22,1963 \ldots \ldots \ldots \ldots \ldots \ldots \ldots \ldots \ldots \ldots \ldots \ldots \ldots \ldots$ 2:815

United States: Arms agreement, signed November 14,

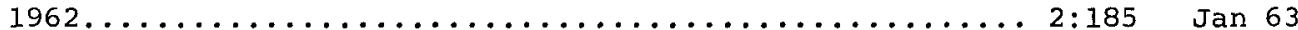

Indonesia: Atomic energy agreement, signed August 8, 1963.... 2:892 Sep 63

Japan: Treaty of amity and commerce, signed July 1 ,

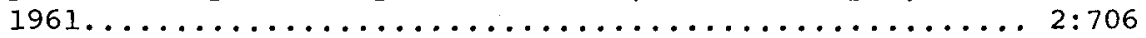

Malaya and Philippines: Joint statement and declaration on the establishment of Malaysia and on "Mapilindo," August 3, 1963......................... 2:871

Netherlands. Agreement concerning West New Guinea (West

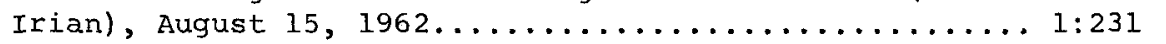

Intergovernmental Committee for European Migration: Revised draft articles of the Guarantee Fund for Assistance to

Group settlements, January $23,1963 \ldots \ldots \ldots \ldots \ldots \ldots \ldots \ldots \ldots \ldots \ldots \ldots$ May 63 International Atomic Energy Agency:

Vienna Convention on Civil Liability for Nuclear Damage,

opened for signature May 21, 1963.............. 2:727 Jul 63

Japan and United States: Agreement for the application of safeguards to the Japan-United states atomic energy agreement, signed september $23,1963 \ldots \ldots \ldots \ldots \ldots \ldots \ldots$ 2:1035

International Civil Aviation Agency: Convention on offences and certain other acts committed on board aircraft, opened for signature september $14,1963 \ldots \ldots \ldots \ldots \ldots \ldots \ldots \ldots \ldots \ldots \ldots \ldots$ 2: 1042

Internationa1 Coffee Agreement, 1962, opened for signature

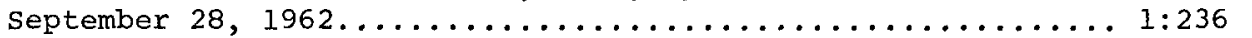

Iraq, Syria, and United Arab Republic: Declaration of agree-

ment for a federal union, April 17, 1963.............. 2:559 May 63

Ireland and United States: Atomic energy agreement amendment, signed August $7,1963 \ldots \ldots \ldots \ldots \ldots \ldots \ldots \ldots \ldots \ldots \ldots \ldots \ldots$. 2:892

Israel and United States: Convention on extradition, signed

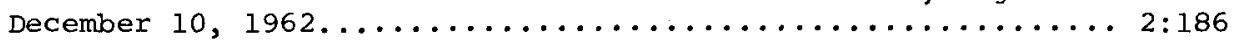

Investment guaranty agreement (first extended risk agreement), signed February 5 and $20,1963 \ldots \ldots \ldots \ldots \ldots \ldots .783$ Japan:

United Kingdom: Treaty of commerce, establishment, and navigation, signed November 14, 1962............ 2:151 United Kingdom statement on the treaty, November

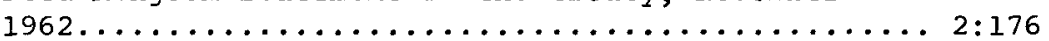

United States: Consular convention, signed March 22,

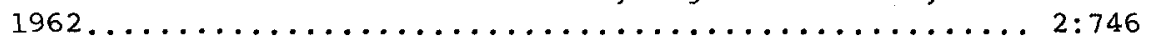
Atomic energy agreement amendment, signed August 7 ,

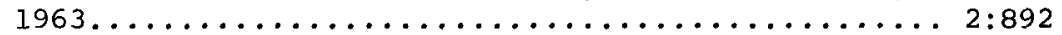

Textile agreement, signed August 27, 1963........ 2:1047

Malaya, North Borneo, Sarawak, Singapore, and United Kingdom: Agreement to form Malaysia, signed July 9, 1963, and draft Constitution............................. 2:816

Mexico and United States: Convention for the solution of the problem of the Chamizal, signed August 29, 1963.......... 2:874

Organization of African Unity: Charter, May 25, 1963....... 2:766 Organization of Central American states: Charter, signed

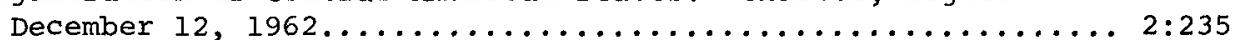

Organization for Economic Co-operation and Development: Draft convention on the protection of foreign property, released to public December $1962 . \ldots \ldots \ldots \ldots \ldots \ldots \ldots \ldots \ldots \ldots \ldots \ldots \ldots \ldots \ldots \ldots$ 2: 241

Jul 63

sep 63

Oct 62

Nov 63

Nov 63

oct 62

Sep 63

$\operatorname{Jan} 63$

Jul 63

$\operatorname{Jan} 63$

$\operatorname{Jan} 63$

JuI 63

Sep 63 Nov 63

Sep 63

Sep 63 Jul 63

Mar 63 
Panama and United States: Agreement on certain procedura1

matters in the canal zone, January 10, $1963 \ldots \ldots \ldots \ldots \ldots \ldots \ldots 2: 268$

Announcement of agreements regarding the Canal zone,

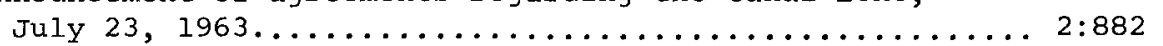

Philippines and United states: Atomic energy agreement amend-

ment, signed August $7,1963 \ldots \ldots \ldots \ldots \ldots \ldots \ldots \ldots \ldots \ldots \ldots \ldots \ldots \ldots$
Spain and United States: Defense agreement renewal, signed

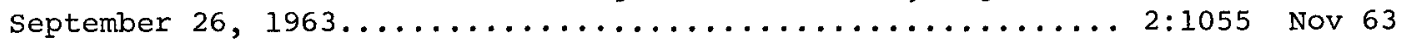

Switzerland and Senegal, Niger, Guinea, and Ivory Coast:

Agreements concerning trade, protection of investments,

and technical cooperation, signed August 16, $1963 \ldots \ldots \ldots \ldots .2: 144$ Jan 63

Union of Soviet Socialist Republics:

United Kingdom: Agreement on relations in the scien-

tific, technological, educational, and cultural fields,

1963-1965, signed January 21 , 1963.............. 2:270

United states: Summary of understandings between the

National Aeronautics and space Administration of the

U.S. and the Academy of Sciences of the U.S.S.R.,

signed June 8, 1962, released December 5, 1962........ 2:195

Memorandum on cooperation in the field of atomic

energy, signed May $21,1963 \ldots \ldots \ldots \ldots \ldots \ldots \ldots$ 2:786

Exchange of views on nuclear test ban, released

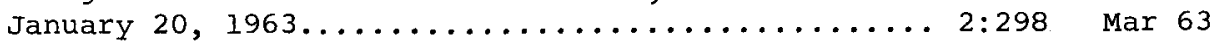

Memorandum of understanding regarding the estab-

lishment of a direct communications link, signed

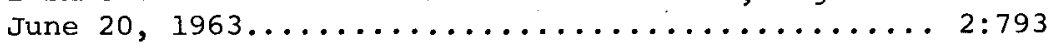

Agreement between the National Aeronautics and

Space Administration of the U.S. and the Academy

of Sciences of the U.S.S.R. for cooperation con-

cerning weather satellites, effective August 1 ,

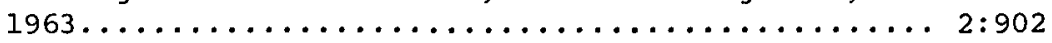

United States and United Kingdom: Nuclear test ban

treaty, signed August $5,1963 \ldots \ldots \ldots \ldots \ldots \ldots \ldots \ldots \ldots \ldots$ 2:883

United Kingdom and United States: Joint statement on nuclear

defense systems (Nassau agreement), December 21, 1962...... 2:279

Polaris sales agreement, April 6, 1963............. 2:595

Letter from U.S. Secretary of State to British

Ambassador regarding the agreement, April 6, 1963.. 2:607

United Nations: Secretary-General's report on agreement for

military disengagement in Yemen, April 29, 1963......... 2:608

United states: Treaties of friendship, commerce and naviga-

tion with Latin American countries as of April 1, 1962..... 1:91

Accession list of investment guaranty agreements as of

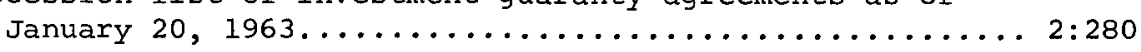

Treaties signed by the United states not yet in force as

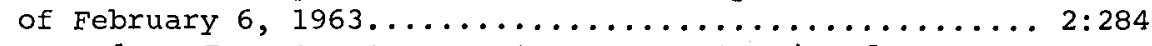

Venezuela: Investment guaranty agreement, signed Novem-

ber $29,1962 \ldots \ldots \ldots \ldots \ldots \ldots \ldots \ldots \ldots \ldots \ldots \ldots \ldots \ldots \ldots \ldots \ldots \ldots$ 2: 282

$\operatorname{Jan} 63$

Jul 63

JuI 63

Sep 63

Sep 63

Mar 63

May 63

May 63

May 63

Aug 62

$\operatorname{Mar} 63 \cdot$

Mar 63

$\operatorname{Mar} 63$

OTHER DOCUMENTS

United Nations: General Assembly Resolutions.

1803 (XVII), on permanent sovereignty over natural

resources, December 14, 1962................ 2:223

1874 (S-IV), general principles to serve as guide-

lines for the sharing of the costs of future

peace-keeping operations, June $27,1963 \ldots \ldots \ldots \ldots$... 2:799

1875 (S-IV), United Nations Emergency Force: cost estimates and financing for the period 1 July to

31 December 1963, June 27, 1963............. 2:801

1876 (S-IV), United Nations operation in the congo: cost estimates and financing for the period $1 \mathrm{July}$ to 31 December 1963, June 27, 1963............ 2:804

$\operatorname{Jan} 63$

1877 (S-IV), payment of arrears in respect of as-

sessed contributions to the United Nations Emer-

gency Force special account and the ad hoc account

for the United Nations operation in the congo,

June $27,1963$. 


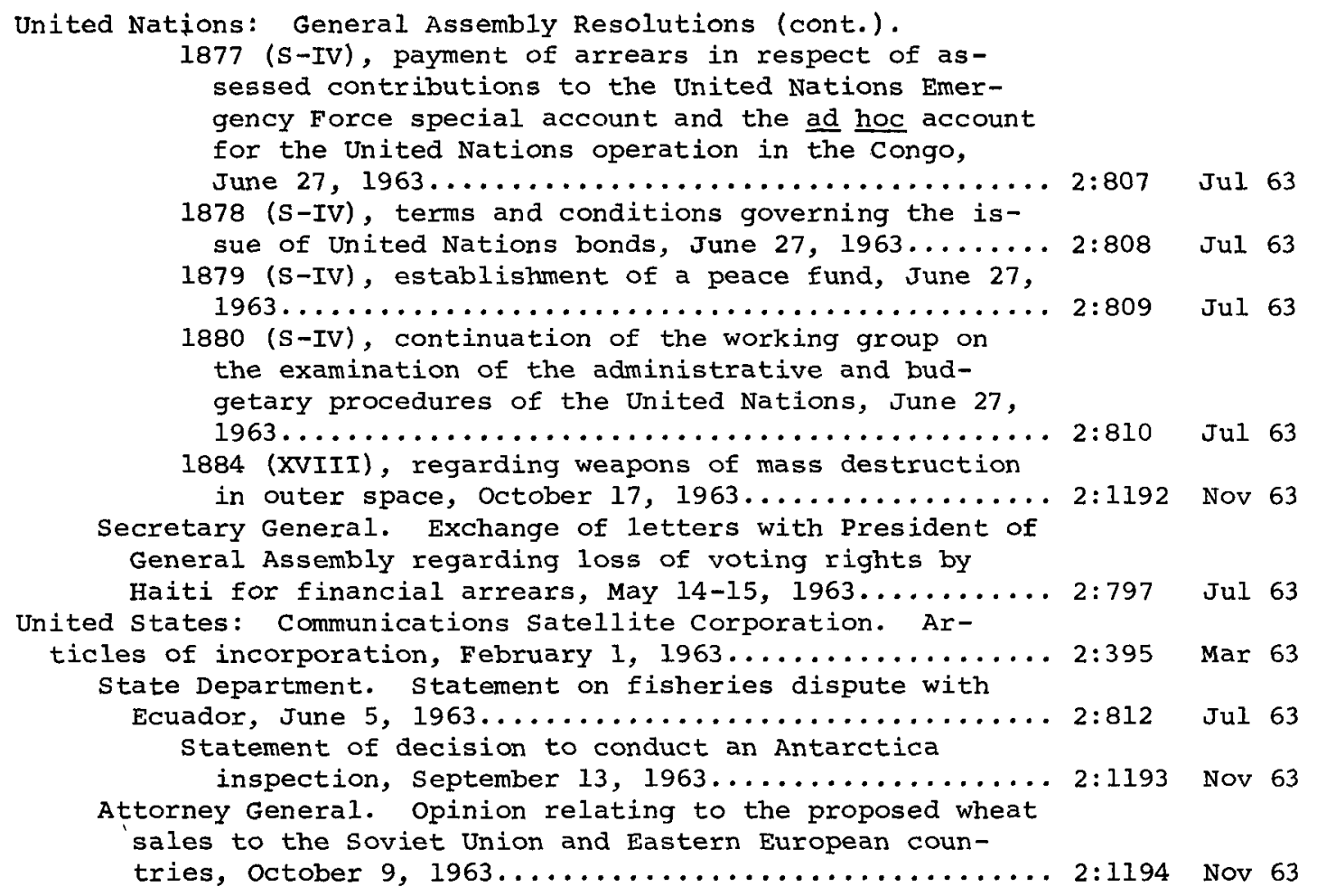

Published by:

American Society of International Law

2223 Massachusetts Avenue, N.W.

Washington 8 , D.C. 


\section{INIERNATIONAL LEGAL MATERIALS}

\section{CURRENT DOCUMENTS}

VOLUME II

NUMBER 1

JANUARY 1963

The American Society of International Law 2223 Massachusetts Avenue, N.W.

WASHINGTON 8, D.C. 
Editor

H. C. L. Merillat

Assistant Editor

Richard W. Edwards, Jr.

Production

Ellen Morris McClellan

Editorial Advisory Committee

Stanley D. Metzger

Arthur S. Miller

Walter S. Surrey 
International Legal Materials is a collection of current official documents designed to meet needs for up-todate information by scholars, practicing lawyers, legal advisers to government agencies and corporations, national and international officials, and others concerned with the legal aspects of public and private international dealings. The documents fall into two main groups: current materials not available in more permanent collections until a later date; and recent materials, likely to be of interest to a broad group of readers, that are not readily available in any other form in most law libraries.

The term international law is interpreted broadly for the purposes of this publication. Some of the materials may be of a kind normally classified under other rubrics, such as foreign law, comparative law, conflicts of law, constitutional law, international organization, and the like. The main criterion in selecting materials is that the document be of substantial interest to a large number of legal scholars, practicing lawyers, and officials dealing with public and private international matters. It is recognized that these interests may vary considerably among users of the publication in the United states and elsewhere.

Technical matters covered by more highly specialized publications, such as tax law in the United States and elsewhere, are normally excluded. Articles, speeches, commentaries, and reports by individuals and private organizations are also excluded.

We try to reproduce the original documents whenever possible within our deadlines. In some instances, however, the documents appear in typewritten form -- for example, when the material is not yet available in an official printing or when excerpts are used. 
REPORTS

European Economic Community: Commission's Action Programme for the Second Stage . . . . . . . . 1

United Nations: Report on plans for constitutional arrangements in the congo.

LEGISLATION AND REGULATIONS

Brazil: Regulations relating to the expatriation of profits earned by foreign investors . . . . . . . . . . . . . . . 100

European Economic Community: Practical Guide concerning Articles 85 and 86 of the Treaty . . . . 104 Communiques relating to exclusive dealership agreements and patent license agreements . . . . . . 138

\section{TREATIES AND AGREEMENTS}

Switzerland: Commercial agreements with Senegal, Niger, Guinea, and Ivory Coast . . . . . . 144

United Kingdom: Treaty of Commerce, Establishment and Navigation with Japan . . . . . . 151 Statement of the Government on the Treaty . . . . . 176

United States and India: Agreement on military assistance . . . . . . . . . . . . . 185

United States and Israel: Convention on extradition. . . . . . . . . . . . . . . . 186

United States and U.S.S.R.: Understandings relating to cooperation in certain space activities. . . . . . . . . . . . . . 195 
JUDICIAL AND ARBITRAL PROCEEDINGS

$\underline{\text { Page }}$

International Court of Justice: Communique regarding the South West Africa Cases. . . . . . . . . 199

United States: Notes on Recent Cases. . . . . . . . 205

Solicitor General's Memorandum in

Sabbatino Case . . . . . . . . . . . . . . 212

NOTICE OF OTHER RECENT DOCUMENTS (not reprinted). . . • . • . 222

SUPPLEMENT

United Nations: General Assembly

Resolution on Permanent Sovereignty

over Natural Resources . . . . . . . . . . . . 223 